\title{
Protease Supplementation under Amino Acid Reduction in Diets Formulated with Different Nutritional Requirements for Broilers
}

\section{-Author(s)}

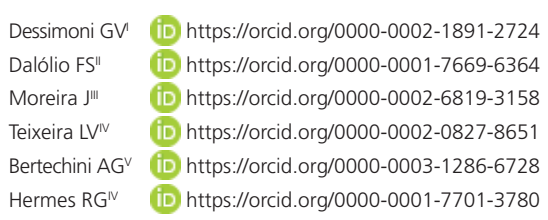

Departamento de Zootecnia, Universidade Estadual Paulista Júlio de Mesquita Filho, Jaboticabal, São Paulo, Brazil.

" Departamento de Engenharia Agrícola, Universidade Federal de Viçosa, Viçosa, Minas Gerais, Brazil.

III Departamento de Zootecnia, Universidade Federal dos Vales do Jequitinhonha e Mucuri, Diamantina, Minas Gerais, Brazil.

DSM Nutritional Products, São Paulo, São Paulo, Brazil

Departamento de Zootecnia, Universidade Federal de Lavras, Minas Gerais, Brazil.

\section{Mail Address}

Corresponding author e-mail address Felipe Santos Dalólio

Avenida Peter Henry Rolfs, s/n - Campus Universitário, Viçosa - MG, 36570-900 -

Brazil.

Phone: (5538) 998643655

Email: felipesantos181@hotmail.com

\section{ABSTRACT}

This study aimed to evaluate the effect of different reductions in digestible amino acids content (lysine, methionine, and threonine), according to two nutritional requirements in corn, soybean meal, and meat and bone meal based diets, with protease supplementation, on performance parameters and carcass characteristics. A total of 1080 day-old chicks, male, Cobb 500, were allotted to a completely randomized design, in a factorial arrangement $3 \times 2$, three reductions in digestible amino acids content (lysine, methionine, and threonine) and two nutritional requirements (Rostagno et al. 2005 and Cobb-Vantress Guidelines 2008), and all diets were supplemented with protease (200 ppm) with 6 replicates of 30 birds per pen. There was no significant interaction $(p<0.05)$ between digestible amino acid reductions and both nutritional requirements for the performance variables and carcass yield and cuts. There was an effect of amino acid reduction and protease supplementation only on slaughter weight $(p<0.05)$. Broilers fed according to the nutritional requirements of Rostagno et al. (2005) showed better $(p<0.05)$ performance when compared to broilers fed as specified by the nutritional requirements of Cobb-Vantress (2008) with no significant differences in carcass characteristics. Protease supplementation of corn, soybean meal, and meat and bone meal based diets allows a reduction in the inclusion of crystalline amino acids (lysine, methionine, and threonine).

\section{INTRODUCTION}

Animal nutrition knowledge has been one of the factors responsible for driving productivity rates in the broiler industry. In Brazil, poultry feed is based on corn, soybean meal and meat bone meal. However, it is well known that the presence of antinutritional factors as trypsin inhibitors, lecithins and allergenic proteins in soybean meal (Rocha et al., 2014); non-starch polysaccharides and phytate in corn (Cowieson et al., 2010), and high variability of nutrient and energy composition in meat and bone meal (Troni et al., 2016), which can affect the nutritional value, utilization and digestibility of these feed ingredients, causing digestive losses to the broilers as well as reducing its performance.

Protease supplementation in diets for broilers is a relevant tool to improve the efficiency in utilizing vegetable and animal protein (Stefanello et al., 2016; Vieira et al., 2016; Cowieson et al., 2018). Protease promotes a higher degradation of antinutritional factors present in feedstuffs improves protein digestibility and decreases synthesis of endogenous enzymes, resulting in higher availability of amino acids for protein deposition (Angel et al., 2011; Kamel et al., 2015).

In order to meet broiler's requirements, different nutritional recommendations can be used in association with enzymes added to 
Dessimoni GV, Dalólio FS, Moreira J, Teixeira LV, Bertechini AG, Hermes RG
Protease Supplementation under Amino Acid Reduction in Diets Formulated with Different Nutritional Requirements for Broilers diets (Oliveira et al., 2012). Crude protein and digestible lysine levels are the variables with highest variation among nutritional plans, as they are among the most expensive components and an excess or deficiency will lead to amino acid imbalance. Therefore, formulation based on the ideal protein concept is able to provide a better balance in the ratio between digestible amino acids (methionine + cystine, lysine and threonine) and crude protein, thus increasing poultry productivity (Wu, 2014).

Choosing an appropriate nutritional recommendation with the inclusion of protease in the diet can lead to an increase in the availability of amino acids, once, overestimated the true amino acid digestibility of ingredients in diets supplemented with protease can be an alternative to reduce the inclusion of crystalline amino acids, consequently, reducing feed costs.

Thus, the objective of the present study was to evaluate the effect of different reductions in the amounts of digestible amino acids (lysine, methionine, and threonine), and two nutritional recommendations in corn, soybean meal, and meat and bone meal based diets, with protease supplementation on broilers performance and carcass characteristics.

\section{MATERIAL AND METHODS}

The study was performed according to ethical principles for animal experimentation established by the Brazilian College of Animal Experimentation (Cobea,

Table 1 - Composition of experimental diets for each rearing period according to two nutritional recommendations, NR1 (Rostagno et al., 2005) and NR2 (Cobb-Vanterss, 2008).

\begin{tabular}{|c|c|c|c|c|c|c|}
\hline \multicolumn{7}{|l|}{ Basal Diet } \\
\hline & \multicolumn{2}{|c|}{ Starter } & \multicolumn{2}{|c|}{ Grower } & \multicolumn{2}{|c|}{ Finisher } \\
\hline Ingredients & $\mathrm{NR}^{1}{ }^{1}$ & $\mathrm{NR}^{2}{ }^{2}$ & $\mathrm{NR} 1^{1}$ & $\mathrm{NR}^{2}{ }^{2}$ & $\mathrm{NR}^{2}{ }^{2}$ & $\mathrm{NR}^{2}{ }^{2}$ \\
\hline Corn $(8 \% C P)$ & 60.39 & 63.54 & 63.06 & 67.39 & 67.33 & 66.51 \\
\hline Soybean meal (46\%CP) & 31.04 & 28.76 & 27.08 & 23.57 & 23.03 & 23.97 \\
\hline Bone and meat meal (45\%CP) & 4.00 & 4.00 & 4.00 & 4.00 & 4.00 & 4.00 \\
\hline Soybean oil & 1.42 & 1.00 & 3.21 & 2.51 & 3.15 & 3.37 \\
\hline Dicalcium phosphate & 0.85 & 0.86 & 0.65 & 0.67 & 0.50 & 0.49 \\
\hline Limestone & 0.61 & 0.62 & 0.55 & 0.55 & 0.50 & 0.50 \\
\hline Salt & 0.37 & 0.37 & 0.34 & 0.34 & 0.31 & 0.31 \\
\hline L-Lysine $\mathrm{HCl}(78 \%)^{3}$ & 0.35 & 0.12 & 0.26 & 0.20 & 0.32 & 0.13 \\
\hline DL-Methionine $(99 \%)^{3}$ & 0.33 & 0.22 & 0.26 & 0.23 & 0.25 & 0.21 \\
\hline L-Threonine $(98 \%)^{3}$ & 0.14 & 0.01 & 0.08 & 0.04 & 0.10 & 0.00 \\
\hline Sodium bicarbonate & 0.10 & 0.10 & 0.10 & 0.10 & 0.10 & 0.10 \\
\hline Kaolin ${ }^{3}$ & 0.10 & 0.10 & 0.08 & 0.08 & 0.10 & 0.10 \\
\hline Mineral supplement ${ }^{4}$ & 0.10 & 0.10 & 0.10 & 0.10 & 0.10 & 0.10 \\
\hline Vitamin supplement ${ }^{5}$ & 0.10 & 0.10 & 0.10 & 0.10 & 0.10 & 0.10 \\
\hline Salinomycin & 0.05 & 0.05 & 0.05 & 0.05 & 0.05 & 0.05 \\
\hline Zinc bacitracin & 0.03 & 0.03 & 0.03 & 0.03 & 0.03 & 0.03 \\
\hline Protease & 0.02 & 0.02 & 0.02 & 0.02 & 0.02 & 0.02 \\
\hline Total & 100.00 & 100.00 & 100.00 & 100.00 & 100.00 & 100.00 \\
\hline \multicolumn{7}{|c|}{ Calculated composition of nutrients } \\
\hline Crude Protein (\%) & 21.47 & 19.97 & 19.50 & 18.38 & 18.21 & 17.33 \\
\hline Met. Energy kcal/kg & 3050 & 3050 & 3150 & 3150 & 3200 & 3200 \\
\hline Dig. Lysine1 (\%) & 1.26 & 1.03 & 1.10 & 0.97 & 1.05 & 0.92 \\
\hline Dig. Methionine $(\%)$ & 0.62 & 0.50 & 0.53 & 0.49 & 0.50 & 0.47 \\
\hline Dig. methionine+cystine ${ }^{1}(\%)$ & 0.90 & 0.78 & 0.80 & 0.74 & 0.76 & 0.72 \\
\hline Dig. Threonine $(\%)$ & 0.82 & 0.67 & 0.73 & 0.63 & 0.68 & 0.60 \\
\hline Calcium (\%) & 0.92 & 0.92 & 0.83 & 0.83 & 0.77 & 0.77 \\
\hline Available P (\%) & 0.46 & 0.46 & 0.41 & 0.41 & 0.38 & 0.38 \\
\hline Sodium (\%) & 0.22 & 0.22 & 0.21 & 0.21 & 0.20 & 0.20 \\
\hline Chlorine (\%) & 0.20 & 0.20 & 0.20 & 0.20 & 0.20 & 0.20 \\
\hline
\end{tabular}

'NR1: Rostagno et al., (2005).

${ }^{2}$ NR2: Cobb-Vanterss (2008).

${ }^{3}$ Ingredients and nutrients that had a variation in the experimental diets.

${ }^{4}$ Mineral Premix: Zinc (110.000 mg), Selenium (360 mg), lodine (1.400 mg), Copper (20.000 mg), Manganese (156.000 mg), Iron (96.000 mg).

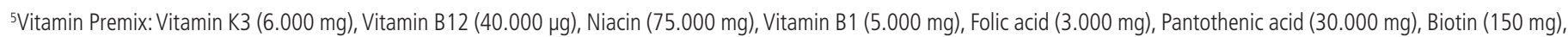
BHT (100 mg), Calcium (82 g), Vitamin B6 (8.000 mg), Vitamin A (25.000.000 UI), Vitamin D3 (6.000.000 UI), Vitamin and (45.000 UI), Vitamin B2 (12.000 mg). 
Dessimoni GV, Dalólio FS, Moreira J, Teixeira LV, Bertechini AG, Hermes RG

\section{Protease Supplementation under Amino Acid Reduction in Diets Formulated with Different Nutritional Requirements for Broilers}

1991) and complying with the current legislation. The trial was performed in the experimental poultry house facilities of the Center for Research in Poultry Technology (CPTA), in a partnership with the Federal University of Lavras (UFLA), state of Minas Gerais, Brazil.

A total of 1080 day-old chicks, male, Cobb 500, allotted to a completely randomized design, in a factorial arrangement $3 \times 2$, three reductions in digestible amino acids content (lysine, methionine, and threonine) and two nutritional recommendations, Brazilian Tables for Poultry and Swine (Rostagno et al., 2005) and the genetic strain guidelines (Cobb-Vantress, 2008), and all diets were supplemented with protease with 6 replicates of 30 birds each one. The product used has 75,000 protease units/g of enzyme, and was added according to the manufacturer's recommendation - 200 ppm (15000 PROT). This protease is manufactured from the fermentation of Bacillus licheniformis containing gene transcripted Nocardiopsisprasina, being considered as a monocomponent protease. The enzyme activity for this enzyme is defined as the amount of enzyme needed to degrade $1 \mu \mathrm{mol} p$-nitroaniline from $1 \mu \mathrm{mol}$ substrate (Suc-Ala-Ala-Pro-Phe-N-succinyl Ala-Ala-ProPhe-p-nitroanilide) per minute at $\mathrm{pH} 9.0$ and $37^{\circ} \mathrm{C}$.

The broilers were housed in 36 boxes $(2.00 \mathrm{x}$ $1.10 \mathrm{~m}$ ) with new wood shaving litter, in a masonry poultry house with cement floor, using a wood heating system, with nipple drinkers and a tubular feeder in each box. The broilers were vaccinated in the hatchery against Marek's disease and on the $10^{\text {th }}$ and $20^{\text {th }}$ day of age against IBD. The lighting program was continuous, 24-hour artificial light. Feed and water were available ad libitum throughout the experimental period. The diets were formulated based on corn, soybean meal, and meat and bone meal (Table 1).

The first amino acid reduction (AR1), lysine, methionine and threonine were previously based on the true amino acid digestibility of the ingredients (corn - 8\% CP; soybean meal - 46\% CP; and meat and bone meal - 45\% CP) supplemented with protease according to study of Pinto (2011), from 14 to $21 \mathrm{~d}$ and 36 to $42 \mathrm{~d}$. In the second (AR2) and third (AR3) amino acid reduction, the true amino acid digestibility of the feed ingredients were overestimate in 20 and $40 \%$, respectively, in the diets supplemented with protease from 14 to $21 \mathrm{~d}$ and 36 to $42 \mathrm{~d}$ (Table 2). The amino acid reduction diets were formulated according to Rostagno et al. (2005) (NR1) and Cobb-Vantress Guidelines (2008) (NR2) recommendations.
The energy and mineral levels were adjusted so all the diets would have the same amount of energy and nutrients for each period of the broiler's life. Only the amino acid levels were different based on the nutritional recommendation proposed for each stage. According to the recommendation of Rostagno et al. (2005), the amino acid profile was calculated using the ideal protein concept, establisher lysine as the reference amino acid. The amino acids recommendations of the Cobb-Vantress Guidelines (2008) were followed except for threonine that was calculated according to the ideal protein concept.

Ingredients that underwent alterations in the reductions of amino acids amounts (AR) were: L-Lysine $\mathrm{HCl}$; DL-Methionine; L-Threonine; inert material and protease). Their respective ratios and nutritional compositions are shown in Table 2 for the broilers rearing periods: starter ( 1 to 21 days), grower (22 to 35 days), and finisher (36 to 42 days). Amounts of the other ingredients were maintained.

The performance variables that were analyzed: feed intake (g), weight gain (g), and feed conversion ratio $(\mathrm{g} / \mathrm{g})$. The broilers were weighed on days 1, 21 and 42. To evaluate the slaughter weight, yield of carcass, breast, thigh + drumstick, wing and abdominal fat, two birds were selected at 42 days of age per experimental group, based on the group's average body weight $( \pm 5 \%)$. After an 8-hour fasting period, the broilers were desensitized by electronarcosis, and then slaughtered in a room with blue artificial light. They were eviscerated to evaluate and calculate the yield of carcass, breast, thigh + drumstick, wing and abdominal fat. The carcass yield was quantified adding the head, neck and feet weight. The absolute weight of pancreas was measured to determine if there were alterations resulting from the protease supplementation.

The statistical model used was: Yijk $=\mu+\alpha_{i}+\beta$ $+(\alpha \beta)_{i j}+\varepsilon_{i j k}$, where: $Y_{i j k}$ is the observation $k$ of the $i^{\text {th }}$ amino acid reduction within the $j^{\text {th }}$ nutritional recommendation; $\mu$ is the overall mean; $\alpha_{i}$ is the effect of the $i^{\text {th }}$ amino acid reduction; $\beta$ is the effect of the $j^{\text {th }}$ nutritional recommendation; $(\alpha \beta)_{i j}$ is the interaction of the $i^{\text {th }}$ amino acid reduction $i$ with the $\mathrm{j}^{\text {th }}$ nutritional recommendation; $\varepsilon_{\mathrm{ijk}}$ is the residual random error.

Data were analyzed by ANOVA procedure based on a completely randomized factorial design. The data statistical analysis was performed using the GLM procedure of SAS (SAS, 2002) and the means were compared by Tukey's test, at 5\% probability. 
Table 2 - Ingredients that underwent alterations in the experimental diets for the starter (1 to 21 days), grower (22 to 35 days) and finisher (36 to 42 days) periods of broiler rearing according to two nutritional recommendations (NR) and three reductions in the amount of amino acids (AR).

\begin{tabular}{|c|c|c|c|c|c|c|}
\hline \multirow[b]{3}{*}{ Ingredients (g. $\left.\mathrm{kg}^{-1}\right)$} & \multicolumn{6}{|c|}{ Starter -1 to 21 days } \\
\hline & \multicolumn{3}{|c|}{ Rostagno et al. (2005) NR1 } & \multicolumn{3}{|c|}{ Cobb-Vantress (2008) (NR2) } \\
\hline & AR1 & AR2 & AR3 & AR1 & AR2 & AR3 \\
\hline L-Lysine $\mathrm{HCl}^{1}$ & 0.3240 & 0.3190 & 0.3135 & 0.1035 & 0.0990 & 0.0953 \\
\hline DL-Methionine ${ }^{1}$ & 0.2849 & 0.2760 & 0.2679 & 0.1851 & 0.1780 & 0.1706 \\
\hline L-Threonine $^{1}$ & 0.0518 & 0.0340 & 0.0167 & 0.0000 & 0.0000 & 0.0000 \\
\hline |nert material ${ }^{1}$ & 0.2366 & 0.2680 & 0.2992 & 0.1436 & 0.1550 & 0.1663 \\
\hline Protease $^{1}$ & 0.0200 & 0.0200 & 0.0200 & 0.0200 & 0.0200 & 0.0200 \\
\hline \multicolumn{7}{|c|}{ Calculated Composition of Nutrients(\%) } \\
\hline Dig. Lysine ${ }^{1}$ & 1.2410 & 1.2370 & 1.2330 & 1.0190 & 1.0160 & 1.0110 \\
\hline Dig. Methionine ${ }^{1}$ & 0.6010 & 0.5980 & 0.5950 & 0.4920 & 0.4900 & 0.4880 \\
\hline Dig. Meth.+Cyst. ${ }^{1}$ & 0.8540 & 0.8460 & 0.8370 & 0.7410 & 0.7340 & 0.7270 \\
\hline \multirow[t]{3}{*}{ Dig. Threonine ${ }^{1}$} & 0.7410 & 0.7250 & 0.7090 & 0.6660 & 0.6660 & 0.6660 \\
\hline & \multicolumn{6}{|c|}{ Grower -22 to 35 days } \\
\hline & \multicolumn{3}{|c|}{ Rostagno et al. (2005) NR1 } & \multicolumn{3}{|c|}{ Cobb-Vantress (2008) (NR2) } \\
\hline Ingredients $\left(\mathrm{g} \cdot \mathrm{kg}^{-1}\right)$ & AR1 & AR2 & AR3 & AR1 & AR2 & AR3 \\
\hline L-Lysine $\mathrm{HCl}^{1}$ & 0.2324 & 0.2262 & 0.2200 & 0.1699 & 0.1640 & 0.1594 \\
\hline DL-Methionine ${ }^{1}$ & 0.2397 & 0.2363 & 0.2330 & 0.2238 & 0.2220 & 0.2197 \\
\hline L-Threonine' & 0.0607 & 0.0563 & 0.0520 & 0.0164 & 0.0120 & 0.0084 \\
\hline Inert material ${ }^{1}$ & 0.1304 & 0.1445 & 0.1580 & 0.1364 & 0.1480 & 0.1590 \\
\hline Protease $^{1}$ & 0.0200 & 0.0200 & 0.0200 & 0.0200 & 0.0200 & 0.0200 \\
\hline \multicolumn{7}{|c|}{ Calculated Composition of Nutrients(\%) } \\
\hline Dig. Lysine ${ }^{1}$ & 1.0750 & 1.0700 & 1.0650 & 0.9460 & 0.9402 & 0.9380 \\
\hline Dig. Methionine ${ }^{1}$ & 0.5230 & 0.5220 & 0.5210 & 0.4850 & 0.4830 & 0.4820 \\
\hline Dig. Meth.+Cyst. ${ }^{1}$ & 0.7740 & 0.7710 & 0.7680 & 0.7340 & 0.7320 & 0.7300 \\
\hline \multirow[t]{3}{*}{ Dig.Threonine 1} & 0.6940 & 0.6900 & 0.6860 & 0.6100 & 0.6070 & 0.6030 \\
\hline & \multicolumn{6}{|c|}{ Finisher -36 to 42 days } \\
\hline & \multicolumn{3}{|c|}{ Rostagno et al. (2005) NR1 } & \multicolumn{3}{|c|}{ Cobb-Vantress (2008) (NR2) } \\
\hline Ingredients $\left(\mathrm{g} \cdot \mathrm{kg}^{-1}\right)$ & AR1 & AR2 & AR3 & AR1 & AR2 & AR3 \\
\hline L-Lysine $\mathrm{HCl}^{1}$ & 0.2910 & 0.2860 & 0.2802 & 0.1014 & 0.0960 & 0.0910 \\
\hline DL-Methionine $^{1}$ & 0.2310 & 0.2280 & 0.2236 & 0.1914 & 0.1880 & 0.1840 \\
\hline L-Threonine $^{1}$ & 0.0790 & 0.0740 & 0.0690 & 0.0000 & 0.0000 & 0.0000 \\
\hline Inert material ${ }^{1}$ & 0.1530 & 0.1680 & 0.1824 & 0.1242 & 0.1330 & 0.1420 \\
\hline Protease $^{1}$ & 0.0200 & 0.0200 & 0.0200 & 0.0200 & 0.0200 & 0.2020 \\
\hline \multicolumn{7}{|c|}{ Calculated Composition of Nutrients(\%) } \\
\hline Dig. Lysine ${ }^{1}$ & 1.0260 & 1.0220 & 1.0170 & 0.9010 & 0.8980 & 0.8940 \\
\hline Dig. Methionine ${ }^{1}$ & 0.5010 & 0.5000 & 0.4990 & 0.4640 & 0.4630 & 0.4620 \\
\hline Dig. Meth.+Cyst. ${ }^{1}$ & 0.7360 & 0.7320 & 0.7280 & 0.7040 & 0.7000 & 0.6970 \\
\hline Dig. Threonine ${ }^{1}$ & 0.6580 & 0.6540 & 0.6490 & 0.5990 & 0.5990 & 0.5990 \\
\hline
\end{tabular}

'Ingredients and nutrients that had a variation in the experimental diets.

AR1- Amino acids reduction 1 (with protease and amino acids reduction, considering real digestibility); AR2- Amino acids reduction 2 (with protease and amino acids reduction, considering 20\% higher digestibility); AR3- Amino acids reduction 3 (with protease and amino acids reduction, considering $40 \%$ higher digestibility).

\section{RESULTS AND DISCUSSION}

There was no significant interaction $(p<0.05)$ between the reductions in digestible amino acids (methionine, lysine and threonine) amounts and the two nutritional recommendations for the performance variables of broilers from 1 to 21 and from 1 to 42 days of age (Table 3 ). However, the recommendations of Rostagno et al. (2005) increased weight gain and decreased feed conversion ratio $(p<0.05)$ when compared to the Cobb-Vantress Guidelines (2008) in all evaluated periods.

Toledo et al. (2007) evaluated two nutritional den-sities (standard and low), by adding enzymes (amylase, xylanase and protease), in the starter period and found no significant interaction between the nutritional densities and the enzyme complex on performance variables and bioeconomic index. According to Oxenboll et al. (2011), including protease in broiler diets with different protein levels does not 
Table 3 - Performance of broilers fed diets formulated according to two nutritional recommendations with different reductions of digestible amino acid amounts with protease supplementation from 1 to 21 and 1 to 42 days of age.

\begin{tabular}{|c|c|c|c|}
\hline \multirow[b]{2}{*}{ Amino acid reduction (AR) } & \multicolumn{3}{|c|}{1 to 21 days } \\
\hline & WG (g) & $\mathrm{FI}(\mathrm{g})$ & $\mathrm{FCR}(\mathrm{g} / \mathrm{g})$ \\
\hline AR1 & 838 & 1237 & 1.48 \\
\hline AR2 & 847 & 1245 & 1.47 \\
\hline AR3 & 841 & 1237 & 1.47 \\
\hline \multicolumn{4}{|c|}{ Nutritional recommendation (NR) } \\
\hline NR1(Rostagnoet al. 2005) & $855 a$ & 1243 & $1.45 \mathrm{a}$ \\
\hline NR2 (Cobb-Vantress, 2008) & $828 b$ & 1236 & $1.49 \mathrm{~b}$ \\
\hline \multicolumn{4}{|l|}{$p$ value } \\
\hline$A R$ & 0.6258 & 0.7343 & 0.8065 \\
\hline NR & 0.0015 & 0.5043 & $<0.0001$ \\
\hline$A R \times N R$ & 0.7303 & 0.5295 & 0.8195 \\
\hline \multirow[t]{2}{*}{$\mathrm{CV}(\%)$} & 2.64 & 2.40 & 1.69 \\
\hline & \multicolumn{3}{|c|}{1 to 42 days } \\
\hline Amino acid reduction (AR) & WG (g) & $\mathrm{FI}(\mathrm{g})$ & FCR $(g / g)$ \\
\hline AR1 & 2788 & 4890 & 1.75 \\
\hline AR2 & 2767 & 4893 & 1.77 \\
\hline AR3 & 2774 & 4995 & 1.78 \\
\hline \multicolumn{4}{|c|}{ Nutritional recommendation (NR) } \\
\hline Rostagnoet al. (2005) & $2831 \mathrm{a}$ & 4901 & $1.73 \mathrm{a}$ \\
\hline Cobb-Vantress (2008) & $2728 b$ & 4902 & $1.80 \mathrm{~b}$ \\
\hline \multicolumn{4}{|l|}{$p$ value } \\
\hline$A R$ & 0.6193 & 0.3515 & 0.1041 \\
\hline NR & $<0.0001$ & 0.4579 & $<0.0001$ \\
\hline$A R \times N R$ & 0.2085 & 0.9383 & 0.2426 \\
\hline CV $(\%)$ & 1.96 & 2.07 & 1.85 \\
\hline
\end{tabular}

WG = weight gain; $\mathrm{Fl}$ = feed intake; $\mathrm{FCR}=$ feed conversion ratio; $\mathrm{CV}=$ coefficient of variation (\%); $\mathrm{P}$ value = probability; $\mathrm{AR} \times \mathrm{NR}=$ interaction between the reduction in digestible amino acid amounts and nutritional recommendations. Means followed by different letters in the columns are different according to Tukey's test $(p<0.05)$. AR1- Digestible amino acids reduction 1 (with protease and amino acid reduction considering the ingredients real digestibility (Pinto, 2011); AR2- Digestible amino acids reduction 2 (with protease and amino acid reduction considering ingredients digestibility 20\% higher than true); AR3- Digestible amino acids reduction 3 (with protease and amino acid reduction considering ingredients digestibility $40 \%$ higher than true).

affect feed intake and feed conversion ratio at 42 days of age. Freitas et al. (2011) evaluated different nutritional plans with variable metabolizable energy and crude protein in diets with or without protease supplementation. The authors found no effect on the body weight of broilers at 42 days, and a quadratic effect on feed conversion ratio when protease was included in the formulation. Broilers fed diets with the highest protein level had better performance. Angel et al. (2011) reported similar results in broilers up to 21 days of age. According to these authors, protease was more active with a higher amount of protein substrate and the same amount of metabolizable energy.

Based on data of the present study, it was found that adding protease in diets for broilers lead to the possibility of considering the digestibility of amino acids (lysine, methionine, and threonine) present in feed ingredients up to $40 \%$ higher than the real digestibility, independently of crude protein level and synthetic amino acids used in different nutritional plans. According to Freitas et al. (2011), the effect of supplementing protease is more pronounced in broiler diets with higher amounts of crude protein. This statement is in agreement with the results obtained in this study, where the nutritional recommendations by Rostagno et al. (2005), supplying a higher amount of crude protein than recommended by the CobbVantress Guidelines (2008), provided better results for the same performance variables evaluated.

According to Silva et al. (2001) the lower ratio of metabolizable energy and crude protein (ME:CP) affect performance increasing weight gain. It directly influences the pool of amino acids for protein deposition and uric acid synthesis as well as in the supply of carbohydrate and fat to meet the energetic requirements of the broiler chickens. According to the NRC (1994) the ME:CP for broilers should be 160 for the highest performance. In the present study, it was observed that the average ME:CP was 158 and 168 by recommendation of Rostagno et al. (2005) and Cobb-Vantress (2008), respectively. This fact also contributed to the improvements of broilers 
performance fed diets formulated according to Rostagno et al. (2005).

It is known that broilers require essential amino acids and not crude protein and nitrogen amounts that are sufficient for the synthesis of non-essential amino acids (Vasconcellos et al., 2010). It is also known that protein absorption from the intestinal lumen takes place as diand tripeptides. This could be the reason for a better broiler performance with a high-protein diet. The enzyme-substrate specificity and non-standardization of protein feed ingredient, mainly from animal origin, may be an explanation for the absence of the effect on broiler performance in the diets supplemented with exogenous serine-protease (Vieira et al., 2004; 2016), as in the present study.

Besides that, one of the main factors is the level of digestible lysine in the diet as all other limiting amino acids are calculated as a function of lysine. Thus, when there is an unbalance of a certain digestible amino acid, namely lysine, there are deamination and transamination reactions with donation and/or degradation of its respective amino groups, moving the amino acid function to other functions such as excretion of its metabolism products (Dalólio et al. 2016). Rodrigues et al. (2008) claim that the digestible lysine:crude protein ratio in the diet is very important and should be maintained around 5.90\% until 42 days. In the present study this ratio was $5.77 \%$ and $5.31 \%$ in the Rostagno et al. (2005) and Cobb-Vantress Guidelines (2008), respectively. Goulart et al. (2011) stressed that the methionine+cystine:digestible lysine ratio in the grower phase should be around $72 \%$, as recommended by Rostagno et al. (2005), while in the Cobb-Vantress Guidelines (2008), this ratio was $76.30 \%$.
Thus, the methionine+cystine concentration imbalance in the diet could be a determinant factor in limiting the growth of broilers fed diets formulated according to the recommendations for the Cobb-500 strain.

As to the carcass characteristics and absolute weight of the pancreas at 42 days (Table 4), there was no isolated effect or a significant interaction ( $p>0.05)$ between the reduction of synthetic amino acid (lysine, methionine and threonine) and the two nutritional recommendations, Rostagno et al. (2005) and CobbVantress (2008). There was effect $(p<0.05)$ of amino acid reduction and protease supplementation only at slaughter weight, being that when overestimating the digestibility of the ingredients (corn, soybean meal and meat and bone meal) of the diet up to $40 \%$ (AR3) the slaughter weight was lower in relation to the digestibility of the ingredients (AR1). Dosković et al. (2016) did not observe effect on slaughter weight of 49-day-old broiler chickens fed diets supplemented with protease and different levels of crude protein. According to Makhdum et al. (2013), slaughtering weight tends to be higher when supplementing enzymes in diets based on high-fiber feed ingredients. However, this fact did not occur in the present study, where the diets were based on corn, soybean meal and meat-and-bone meal. Kamel et al. (2015) reported that the highest level of the major crystalline amino acids (methionine, lysine and threonine) provided in the diets associated with protease supplementation for broilers were the factors that most affected the carcass characteristics, regardless of metabolizable energy level and crude protein. This may led to an increase in the weight of the broiler's viscera, without altering the carcass yield and noble cuts.

Table 4 - Carcass characteristics of broilers at 42 days of age fed diets formulated according to two nutritional recommendations with different reductions of digestible amino acid amounts with protease supplementation.

\begin{tabular}{|c|c|c|c|c|c|c|}
\hline Amino acid reduction (AR) & SW (g) & $C Y^{*}(\%)$ & BY (\%) & TDY (\%) & $\mathrm{AF}(\%)$ & $P(g)$ \\
\hline AR1 & $2885 a$ & 82.87 & 33.85 & 25.62 & 1.73 & 5.02 \\
\hline AR2 & $2791 a b$ & 83.30 & 32.66 & 26.22 & 1.66 & 5.00 \\
\hline AR3 & $2707 \mathrm{~b}$ & 82.41 & 32.64 & 26.06 & 1.78 & 5.07 \\
\hline \multicolumn{7}{|c|}{ Nutritional Recommendation (NR) } \\
\hline Rostagno et al. (2005) & 2791 & 82.58 & 33.28 & 25.70 & 1.69 & 5.00 \\
\hline \multirow[t]{2}{*}{ Cobb-Vantress (2008) } & 2797 & 83.13 & 32.81 & 26.16 & 1.77 & 5.10 \\
\hline & \multicolumn{6}{|c|}{$p$ value } \\
\hline$A R$ & 0.0068 & 0.6794 & 0.1178 & 0.5539 & 0.4476 & 0.9543 \\
\hline NR & 0.8933 & 0.5244 & 0.3764 & 0.4136 & 0.4008 & 0.8206 \\
\hline$A R \times N R$ & 0.8684 & 0.8628 & 0.5464 & 0.9213 & 0.6035 & 0.5260 \\
\hline $\mathrm{CV}(\%)$ & 4.45 & 2.98 & 4.77 & 5.27 & 17.88 & 11.58 \\
\hline
\end{tabular}

$\mathrm{SW}=$ slaughter weight; $C Y^{*}=$ carcass yield with head, neck and feet; $\mathrm{BY}=$ breast yield; TDY = thigh and drumstick yield; $\mathrm{AF}=$ abdominal fat; $\mathrm{P}=\mathrm{pancreas;} \mathrm{CV}=$ coefficient of variation (\%); P value = probability; AR x NR = interaction between the reduction in digestible amino acid amounts and nutritional recommendations. Means followed by different letters in the columns are different according to Tukey's test $(p<0.05)$. AR 1 - Digestible amino acids reduction 1 (with protease and amino acid reduction considering the ingredients real digestibility (Pinto, 2011); AR2- Digestible amino acids reduction 2 (with protease and amino acid reduction considering ingredients digestibility $20 \%$ higher than true); AR3Digestible amino acids reduction 3 (with protease and amino acid reduction considering ingredients digestibility $40 \%$ higher than true). 


\section{Protease Supplementation under Amino Acid Reduction in Diets Formulated with Different Nutritional Requirements for Broilers}

Carcass yield results found in this trial are in agreement with findings of several other authors, as they also did not find any influence of reducing crude protein levels of the diet on these parameters, when followed by amino acid or exogenous enzyme supplementation (Kamram et al., 2008; Rodrigues et al., 2008; Vasconcellos et al., 2010). Yuan et al. (2017) reported an increase in the gene expression of pancreas enzymes when a protease supplement was added to the diet for broilers. Lima et al. (2012) identified an increase in the absolute weight of pancreas in layers when they received an enzyme complex (cellulase, pentosanase, pectinase, amylase, protease, $\beta$-glucanase, phytase) in the diet. In the present trial no effect of amino acid reduction and protease supplementation of the diet were found on the weight of pancreas of broilers at 42 days.

Rodrigues et al. (2008) evaluated different digestible lysine:crude protein ratios and did not find differences in broilers carcass yield. Vasconcellos et al. (2010) studied different levels of crude protein in broiler diets and found no effect on carcass yield. Levels of crude protein, however, had a quadratic effect on breast yield, and the maximum effect was estimated to be $18.28 \%$ between days 22 and 42 .In the present study, the avergae of crude protein content in the diets for broilers from days 22 and 42 was $18.85 \%$ and $17.86 \%$, respectively, for the nutritional recommendations of Rostagno et al. (2005) and the Cobb-Vantress Guidelines (2008). However, there were not effects on carcass and breast yield, which is the main meat cut with higher protein concentration in the carcass.

\section{CONCLUSIONS}

It is possible to reduce the inclusion of crystalline amino acids (lysine, methionine and threonine) in the diets supplemented with protease, considering that their digestibility is up to $40 \%$ higher than the real digestibility when corn, soybean meal and meat and bone meal are used as ingredients. There are differences in relation to the nutritional recommendations for broilers, and the levels recommended by Rostagno et al. (2005) providing better performance, with no effect on carcass yield and broiler cuts when compared to the Cobb-Vantress Guidelines (2008).

\section{ACKNOWLEDGMENTS}

The authors thank CNPq, CAPES and FAPEMIG for the financial support and for providing the scholarship.
And also gratefully acknowledge late Prof. Aldrin Vieira Pires (in memorian) for all his help and suggestions in carrying out research projects.

\section{REFERENCES}

Angel CR, Saylor W, Vieira SL, Ward N. Effects of a monocomponent protease on performance and protein utilization in 7-to 22 day-old broiler chickens. Poultry Science 2011;90(10):22812286.

Cobb-Vantress. Manual de manejo de frangos de corte COBB. Guapiaçu: Cobb-Vantress Brasil; 2008.

COBEA - Colégio Brasileiro de Experimentação Animal. Princípios éticos na experimentação animal. 1991. Available from: http://www.cobea.org. br/etica.htm\#

Cowieson AJ, Bedford MR, Ravindran V. Interactions between xylanase and glucanse in maize-soy-based diets for broilers. British Poultry Science 2010;51(2):246-257.

Cowieson AJ, Abdollahi MR, Zaefarian F, Pappenberger G, Ravindran V. The effect of a mono-component exogenous protease and graded concentrations of ascorbic acid on the performance, nutrient digestibility and intestinal architecture of broiler chickens. Animal Feed Science and Technology 2018;235:128-137.

Dalólio FS, Moreira J, Vaz DP, Albino LFT, Nunes RV, Pinto GVD. Digestible lysine for broilers from different commercial strains in the final phase. Acta Scientiarum. Animal Sciences 2016;38(4):411-416.

Dosković V, Bogosavljević-Bošković S, Perić L, Lukić M, Škrbić Z, Rakonjac $S$, et al. Effect of protease and duration of fattening period on dressing percentage of broiler chickens. Biotechnology in Animal Husbandry 2016;32(4):353-360.

Pinto GVD. Planos nutricionais com suplementação de protease em dietas para frangos de corte [dissertation]. Diamantina (MG): Universidade Federal dos Vales do Jequitinhonha e Mucuri; 2011.

Freitas DM, Vieira SL, Angel CR, Favero A, Maiorka A. Performance and nutrient utilization of broilers fed diets supplemented with a novel mono-component protease. The Journal of Applied Poultry Research 2011;20(3):322-334.

Goulart CC, Costa FGP, Silva JHV, Souza JG, Rodrigues VP, Oliveira CFS. Requirements of digestible methionine+cystine for broiler chickens at 1 to 42 days of age. Revista Brasileira de Zootecnia 2011;40(4):797-803.

Kamel NF, Ragaa NM, El-Banna RA, Mohamed FF. Effects of a monocomponent protease on performance parameters and protein digestibility in broiler chickens. Agriculture and Agricultural Science Procedia 2015;6:216-225.

Kamran Z, Sarwar M, Nisa M, Nadeem MA, Mahmood S, Babar ME, Ahmed S. Effect of low-protein diets having constant energy-to-protein ratio on performance and carcass characteristics of broiler chickens from one to thirty-five days of age. Poultry Science 2008;87(3):468-474.

Lima MR, Costa FGP, Goulart CC, Pinheiro SG, Souza RB, Morais SAN, et al. Nutritional reduction of protein and usage of enzyme in the diet of light layers. Revista Brasileira de Zootecnia 2012;41(9):2055-2063.

Makhdum Z, Rehman H, Larik JM, Bux P, Hammed A. Crude enzymes supplementation in fibrous diet improves performance of commercial broilers. Journal of Applied Animal Research 2013;41(2):218-222.

NRC - National Research Council. Nutrient requirements of poultry. $9^{\text {th }}$ ed Washington: National Academy Press; 1994. 
Dessimoni GV, Dalólio FS, Moreira J, Teixeira LV, Bertechini AG, Hermes RG
Protease Supplementation under Amino Acid

Reduction in Diets Formulated with Different Nutritional Requirements for Broilers
Oliveira JFF, Rodrigues PB, Alvarenga RR, Zangeronimo MG, Lima GFR. Amino acid reduction in broiler diets supplemented with phytase and elaborated according to different nutritional plans. Ciência e Agrotecnologia 2012;36(2):224-232.

Oxenboll KM, Pontoppidan K, Fru-NjiF. Use of a protease in poultry feed offers promising environmental benefits. International Journal of Poultry Science 2011;10(11):842-848.

Rocha C, Durau JF, Barrilli LNE, Dahlke F,Maiorka P. The effect of raw and toasted soybeans on intestinal health, diet digestibility, and pancreas weight of broilers. The Journal of Applied Poultry Research 2014;23(1):71-79.

Rodrigues KF, Rodrigues PB, Freitas RTF, Bertechini AG, Albino LFT, Fassani EJ. Relação lisina digestível:proteína bruta em dietas para frangos de corte no período de 1 a 21 dias de idade: desempenho e metabolismo. Revista Brasileira de Zootecnia 2008;37(3):450-457.

Rostagno HS, Albino LFT, Donzele JL, Gomes PC, Oliveira RFM, Lopes DC, et al. Tabelas brasileiras para aves e suínos:composição de alimentos e exigências nutricionais. $2^{\text {nd }}$ ed. Viçosa: Universidade Federal de Viçosa; 2005.

SAS Institute. SAS user’s guide: statistics. Version 9.0. Cary; 2002.

Silva JHV, Albino LFT, Nascimento AH. Níveis de energia e relações energia: proteína para frangos de corte de 22 a 42 dias de idade. Revista Brasileira de Zootecnia 2001;30(6):1791-1800.

Stefanello C, Vieira SL, Rios HV, Simões CT, Sorbara JOB. Energy and nutrient utilization of broilers fed soybean meal from two different Brazilian production areas with an exogenous protease. Animal Feed Science and Technology 2016;221:267-273.
Toledo GSP, Costa PTC, Silva JH, Ceccantini M, Poletto Junior C. Frangos de corte alimentados com dietas de diferentes densidades nutricionais suplementadas com enzimas. Ciência Rural 2007;37(2):518-523.

Troni AR, Gomes PC, Mello HHC, Albino LFT, Rocha TC. Composição química e energética de alimentos para frangos de corte. Revista Ciência Agronômica 2016;47(4):755-760.

Vasconcellos CHF, Fontes DO, Vidal TZD, Lara LJC, Rodrigues PB, Vasconcelos RJC. Efeitos de diferentes níveis de proteína bruta sobre o desempenho e composição de carcaça de frangos de corte machos de 21 a 42 dias de idade. Ciência e Agrotecnologia 2010;34(4):1039-1048.

Vieira SL, Lemme A, Goldemberg DB, Brugalli I. Responses of growing broilers to diets with increased sulfur amino acids to lysine ratios at two dietary protein levels. Poultry Science 2004;83(8):1307-1313.

Vieira SL, Stefanello C, Cemim HS. Lowering the dietary protein levels by the use of synthetic amino acids and the use of a mono component protease. Animal Feed Science and Technology 2016;221:262-266.

Wu G. Dietary requirements of synthesizable amino acids by animals: a paradigm shift in protein nutrition. Journal of Animal Science and Biotechnology 2014;5(34):1-12

Yuan L, Wang M, Zhang X, Wang Z. Effects of protease and non-starch polysaccharide enzyme on performance, digestive function, activity and gene expression of endogenous enzyme of broilers. PLoS One 2017;12(3):1-13. 